\title{
Is starting simple the path to complexity?
}

\section{Washington}

The best way to understand complex biological systems may well be through integrating different scientific disciplines. But a panel of high-profile scientists agreed last week that the task of achieving this goal is itself inherently complex.

The panel discussion, held in Washington last week, deliberated the concept of interdisciplinary approaches to complex systems. The session came at the end of a threeday meeting on 'Biology: Challenges for the New Millennium', co-sponsored by the American Institute of Biological Sciences and the Smithsonian Institution.

Problems that would benefit from a complex-systems approach include understanding how elements in an ecosystem contribute to environmental change, and how proteins interact to produce particular end results.

"Do you start teaching synthesis in high school and at the undergraduate level?" asked Marvalee Wake, Chancellor's Professor of Integrative Biology at the University of California, Berkeley. "Is that the goal?"

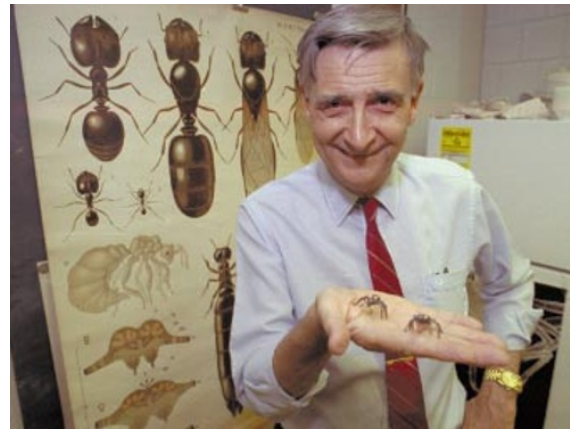

Wilson: begin by understanding one component.

No, said Edward Wilson, honorary curator in entomology of Harvard University's Museum of Comparative Zoology and Pulitzer Prize-winning co-author of The Ants (Harvard, 1990). He advised starting with an understanding of a single component of a system - whether one insect in an ecosystem or one protein in a signal transduction pathway. "When you know enough about basic biology, then you are ready to attack complex systems," said Wilson.
"You have to be really good at something, and then know a little about a lot," echoed Daniel Janzen, professor of biology at the University of Pennsylvania.

Not everyone agreed. Richard Norgaard, president of the International Society for Ecological Economics, which encourages an integrative approach to ecology, argued that complex systems biology and ecology should be emphasized throughout education, not embraced "after your hair turns grey".

Gordon Orians, professor emeritus at the University of Washington, said that, if integration meant literacy in everything, science was setting itself up for "massive failure". Instead, he proposed that biologists should agree on the smallest set of shared knowledge necessary for 'bioliteracy', then be free to develop specialized expertise.

Gene Likens, professor of ecology at Yale and Rutgers, was pessimistic. Scientists would have to embrace complexity and do a better job of communicating with experts from other subdisciplines. "I don't even see us trying," he said.

Paul Smaglik

\section{India and US bring collaboration out of the freezer}

New Delhi

Ragunath Mashelkar, head of India's Council of Scientific and Industrial Research, describes collaboration with the United States as a "frozen chicken" that, as a result of political tensions between the countries, has been left in the freezer for nine years.

Last week, the two countries agreed to set up a joint forum to promote greater interaction between government research institutes, universities and private industry.

Despite its relative lack of funding and an uncertain agenda, Indian officials say that the creation of the forum marks an important step in renewing scientific relations between the two countries. "The forum has brought the chicken out of the freezer for warming up," says Mashelkar.

The agreement was signed by US Secretary of State Madeleine Albright and India's science minister Murli Manohar Joshi during President Bill Clinton's visit to New Delhi. Describing it as "a positive sign", Joshi said that he hoped the forum would give a "new direction" to effective scientific cooperation with the United States.

Neal Lane, Clinton's assistant on science and technology, said the forum would be beneficial to both countries. It is expected to start operating by the end of June.

Scientific cooperation between India and the United States peaked in the 1980s with the launching of some 250 collaborations.
It went downhill in the 1990s, when the United States wanted India to sign the Paris Convention and provide patent protection for products developed on joint programmes. India at first refused to amend its law on intellectual property rights (IPR) allowing patents on processes but not products.

Cooperation was virtually halted by Washington's wish to see India's nuclear missile programme ended, and by the nuclear tests that India carried out two years ago. "The forum is a sign that the door is opening again," says Valangiman Ramamurthi, secretary to the Department of Science and Technology (DST).

But Indian scientists, who had been hoping for more from Clinton - in particular a lifting of the sanctions applied to some 150 Indian research institutes and enterprises after the nuclear tests - were disappointed. "Other than the forum, I can't think of any major [scientific event] during the president's visit, " Ramamurthi admits.

The forum was first proposed three years ago but was put in cold storage over the IPR issue. Last year India did sign the Paris Convention, and an amended patents bill, meeting most of the US demands, awaits a vote in parliament. The forum agreement was signed without an IPR clause that the United States had requested.

"Relaxing IPR means nothing," said an official accompanying Clinton. "Besides, the political environment has improved." But Ramamurthi described the US decision to drop its demand for a clause on IPR as "a significant achievement for us".

The forum will be run by a governing board of seven members from each country. According to A. P. Kulshreshta, head of the international division in the science ministry, it will commission studies and reports on cutting-edge technologies, and promote collaborative projects. The conference did not identify specific areas for collaboration; this will be done in a followup meeting to which industries from both countries will be invited.

Meanwhile, many Indian scientists continue to protest against sanctions on their laboratories. "The right environment should be created for cooperative research," physicist M. G. K. Menon, former science minister, told an Indo-US round-table conference at Hyderabad on 24 March. He described the sanctions as a "thorn" in the relationship between the two countries.

Questions remain over how the forum is likely to function without significant extra funding. The US is not putting any fresh money into the forum, only transferring unspent money - equivalent to $\$ 7$ million - from the now extinct US-India Fund. The forum would operate on the annual interest of $\$ 700,000$, with a matching grant from the Indian government.

K. S. Jayaraman 